\title{
Evaluation of Visual Materials in Social Studies Coursebooks by Teachers' Opinions
}

\author{
Hakkı Yapıc1 \\ Correspondence: Hakkı Yapıc1, Faculty of Literature, Gümüşhane University, Bağlarbaşı, 29100 Merkez, Gümüşhane, \\ Turkey.
}

Received: March 5, 2016 Accepted: March 26, 2016 Online Published: April 19, 2016

doi:10.11114/jets.v4i7.1563

URL: http://dx.doi.org/10.11114/jets.v4i7.1563

\begin{abstract}
The aim of this study is to evaluate the visual elements (picture, photograph, map, table, caricature, etc.) included in the $7^{\text {th }}$-grade Social Studies coursebooks prepared by the Ministry of National Education and taught in 2014-2015 academic year by several variables in accordance with the opinions of Social Studies teachers, with a critical point of view on social studies coursebooks. 120 Social Studies teachers working in 42 secondary schools in Erzurum, Bayburt, and Gümüşhane provinces constituted the study group of the research. Features such as gender, seniority, and the faculty of graduation were discussed in the determination of teachers' opinions. Data of the research were collected with the opinion scale concerning the visual elements in Social Studies coursebooks of a 5-point Likert rating type (strongly agree, agree, neutral, disagree, strongly disagree) containing 18-item Social Studies teachers' opinions (Kırbaş, Orhan and Topal, 2012: 2232). The content validity, intelligibility, and reliability of the scale developed were ensured. The reliability coefficient of the scale was determined as Cronbach's alpha $=0.989$, Bartlett $=5149,741(\mathrm{p}=0.000)$, and the validity coefficient was determined as $\mathrm{KMO}=0.922$. That $\mathrm{KMO}$ result was greater than .50 and Bartlett's test result was significant indicate the suitability of the dataset for the factor analysis. The data obtained were analyzed using SPSS 20.0 package program (percentage, frequency and chi-square test). Item-based frequency (n) and percentage (\%) were used in determining the teachers' opinions.
\end{abstract}

Keywords: social studies coursebook, social studies teachers' opinions, visual elements, scale

\section{Introduction}

Nowadays, having a sufficient number and quality of manpower to overcome problems is possible with an education system which processes data very well, catches the era and which is efficient and even more. Social studies education is one of the cornerstones of such an education system. Therefore, it is necessary to develop and implement social curriculum, methods and techniques, educational technologies with contemporary criteria (Duru and Gürdal, 2002). In today's rapidly changing and developing world, individuals are not expected to get information from a single source and memorize it, on the contrary, it is aimed to raise individuals who know the ways to reach information, who can use them and who can create their solution methods against problems encountered by using information. The use of teaching materials prepared in accordance with the principles of instructional technology is of great importance in individuals' acquisition of these qualifications and in teachers' designing active and interactive learning environments (Şahin and Yildırım, 1999).

Our country continues to experience a process in which teacher factor is at the forefront, and a teaching method that mostly appeals to the sense of hearing is mainly used. In addition to this, it is clear that efficient social studies teaching is required when students' general reluctance status against the social studies course and their low level of success are considered. The place of effective teaching materials in efficient social studies teaching cannot be disputed. Visual teaching materials include graphics, photos, concept maps, slides, films, computer and television screen images, etc. These materials are helpful in directing students, focusing their attention and being able to carry out analysis. These tools should not have the features of disrupting and distracting or diverting students' attention. Using them at the right time and place by considering students' needs will contribute to the increase of impact force (Yalçın, 2003).

Material use in education plays an important role in ensuring students' easier access to anticipated objectives and in achieving the success of the program conducted by preparing an effective educational environment. This is very important for an effective education and training since the element that gives students the actual qualification is the 
curriculum in the educational process. Use of materials in the educational process is vital especially for the success of social studies curriculums (Karamustafaoğlu, 2006).

"Use of materials in the educational process facilitates the perception and learning, arouses interest, and brings dynamism to the classroom. It shortens the time, reinforces the information and helps permanence in learning. It provides students' participation in the subject and arouses the desire to read and research. It brings events, facts, and entities, which are impossible to get near or take to the classroom, into the classroom with their real faces" (Aslan and Doğdu, 1993).

"Tools and materials used in achieving the objective of the educational program have great importance. Coursebooks are the most important tools and materials which have indispensable importance for teachers and students. Coursebooks are the tools aiming to teach the objectives defined in the programs, which are the most widely used tool for students. In the current information age, books are the most important information and cultural tools with which an individual establishes direct relationships. The book plays an important role in the child's development and education. Coursebooks which are the most important tools used by teachers and students in education and training process also have a great importance in achieving the objectives of education. It can be possible to get students acquire the love of books and reading habits only through books which are qualified in terms of content and design" (Kırbaş et al., 2012).

Materials are used to support teaching in the educational process. Materials selected in accordance with the topic and objectives make the topic being taught lively, enrich the teaching process and improve learning. Materials also broaden the students' interests and increase their motivation. Materials are used due to the fact that they provide multiple learning environments, they help students to meet their individual needs, they attract attention, facilitate remembering, materialize the abstract things, save time, and provide an opportunity to make secure observations. Materials are also important as they ensure the presentation of contents which are consistent with each other, they can be used once and again, and they facilitate the understanding by simplifying the contents (Demiralp, 2007).

In another source, "a coursebook is defined as a technical book which is prepared in accordance with the curriculums, written for students of a particular level, used for the purpose of learning, which facilitates learning and remembering, which ranges from easy to difficult and which offers systematic progress and development" (Güneş, 2002). "A coursebook is a printed instructional material used for learning purposes, and it is prepared in accordance with the objectives, content, the educational process included in an instructional program and with the assessment and evaluation dimensions" (Demirel and Kıroğlu, 2005). It is clearly understood from these statements that the coursebook has the feature of being an essential resource in the educational process and attracts attention at the point of being an important material providing classroom discipline.

One of the important aspects of the coursebook is that it is compatible with the methods and techniques being followed in teaching the course. In particular, students' levels, interests, and capacities should be taken into account while creating coursebooks. Evaluation of a book as a coursebook is appreciated to the extent it provides integrity with the subjects of the relevant course. A coursebook which is prepared in this content means that it is a material ready to apply strategies, methods, and techniques required by the objectives and behaviors of the program. Thus, coursebooks play a determining role in education and training activities by incorporating many tools (K1liç and Seven, 2003).

While preparing coursebooks, the fact that teachers teach the current course subjects in the most effective and planned manner and the fact that students learn the subjects in an easy, pleasant and permanent manner are taken into account. The main reason for reading coursebooks is the fact that they are prepared in accordance with the education and training program of the Ministry of National Education. Another reason is the fact that the book is preferred as a teaching tool. Moreover, coursebooks determined by teachers throughout the education term provide convenience for teachers to perform actions such as discussing a subject in a convenient and systematic manner with students, giving homework and objectively assessing student success via exams (Nelson, 1992; Yanpar, 2005).

The fact that coursebooks have features that will attract the students' attention and adapt students to the subject is essential since coursebooks constitute the first-degree resources for students. Here, the stimulants used in the book appear as an important stimulant for students, the most important of which are the visual elements. (Kurbaş et al., 2012). These are the teaching-helping elements such as picture, graph, chart, photograph, plan, and map that explain subjects and enable easier understanding of them. "Coursebooks used in planned educational applications can make teaching and learning process more colorful, interesting and active by including teaching materials such as explanatory, directive, supplementary images, graphics, and shapes" (Küçükahmet, 2001).

"The primary reason for using coursebooks is the fact that they are comprised of an organization prepared in accordance with the program, in other words, they are approved by the Ministry of National Education and Board of Education and Discipline. The second reason is the fact that they are used as teaching materials" (Nelson, 1992, cited by Yanpar, 2005). "The third reason for the selection and use of coursebooks by many teachers is their convenience. It is easy in terms of 
following up and giving homework. Another reason is the purpose of student assessment since coursebooks provide the essence of the information and central information collection" (Taş, 2007).

The importance of visuals in human life is increasing with each passing day, and visuals become an indispensable part of our daily lives. Technological visual tools such as a computer, the Internet, television, signboard, boards and video have great importance in the every area and stage of our domestic and business life. "Today, a student in the USA plays video games and talks on the cell phone for an average of 10 thousand hours and sends or receives 200 thousand e-mail messages up to the age of 21 . There is a television in the bedroom of one of every four children under the age of two. A teenager between the ages of 13-19 watches television for an average of 22 thousand hours" (Prensky, 2001; Bleed, 2005).

Visual symbols, elements, and perceptions make contributions to the formation of new achievements and inventions in the teaching process and acculturation activities of individuals. Thus, this positively affects the communication opportunity, sensing power and the brain structure (left-right brain) of the individual and the cognitive styles and cognitive learning ways (İpek, 2003).

\section{Objective of the Research}

The objective of this study is to evaluate the visual elements (picture, photograph, caricature, map, etc.) in the $7^{\text {th }}$-grade Social Studies coursebooks prepared by the Ministry of National Education which were used in the 2014-2015 academic year with a critical point of view by taking the opinions of Social Studies teachers. As a result of this examination, it was aimed to make suggestions for the book and the visual elements used in the book by evaluating teachers' opinions related to visual elements in coursebooks.

\subsection{Problem Sentence: Answers to the Following Problems Were Sought by This Study Performed}

To what extent do Social Studies teachers find visual elements (picture, photograph, caricature, map, etc.) included in the $7^{\text {th }}$-grade Social Studies coursebooks prepared by the Ministry of National Education according to the 2005 Social Studies curriculum sufficient?

What are the opinions of social studies teachers on the visual elements (picture, photograph, caricature, map, etc.) included in the $7^{\text {th }}$-grade Social Studies coursebooks prepared by the Ministry of National Education according to the 2005 Social Studies curriculum?

\subsection{Premises}

All Social Studies teachers who participated in the research answered the questions in the data collection tool correctly.

\subsection{Limitations}

Research is limited to $7^{\text {th }}$-grade social studies coursebooks prepared by the Ministry of National Education taught in secondary schools in the 2014-2015 academic year.

Research is limited to 120 Social Studies teachers working in 42 secondary schools in Erzurum, Bayburt, and Gümüşhane provinces in the 2014-2015 academic year.

\section{Method}

\subsection{Research Method}

In this study, a survey method which is a way of researching which aims to determine an existing situation with its latest features and which is useful in revealing the main tendencies of individuals, comparing and assuming was applied using tools such as scanning list, interview, etc. "This method attempts to describe and explain "what" the objects, entities, organizations, groups and various fields are. The descriptive research aims to explain the interactions between situations by taking into account the relations of existing events with previous events and conditions. By the studies based on this method, an attempt to find the answer to the questions such as "What is the situation? Where are we?" is made based on the data that are considered to be within the existing time section. The descriptive method which is usually a survey method is a Cross-Sectional study related to the group. These kinds of research are performed on numerous objects or subjects within a given time section" (Kaptan, 1998).

\subsection{Research Sample}

120 Social Studies teachers working in 42 secondary schools in Erzurum, Bayburt, and Gümüşhane provinces constituted the population of the research.

\subsection{Sub-problems of the Research}

1. What are the Social Studies teachers' opinions related to visual elements in Social Studies coursebooks by the variable of gender? 
2. What are the Social Studies teachers' opinions related to visual elements in Social Studies coursebooks by the variable of professional seniority?

3. What are the Social Studies teachers' opinions related to visual elements in Social Studies coursebooks by the variable of the faculty of graduation?

\subsection{Study Group of the Research}

120 Social Studies teachers working in 42 secondary schools which were randomly selected in Erzurum, Bayburt, and Gümüşhane provinces constituted the study group of this research.

\subsection{Data Collection}

In this study conducted with the survey method, the Teachers' Opinions about Visual Elements in Social Studies Coursebooks Scale of a 5-point Likert rating type was used as a data collection tool. Secondary schools to be surveyed were determined to clarify the problem sentence, and then 120 Social Studies teachers who would participate in the research were interviewed face to face, and Social Studies teachers were informed about the subject. Before starting the study, the relevant field scanning was performed on the subject, and similar studies were examined.

The data were collected using the Teachers' Opinions about Visual Elements in Social Studies Coursebooks Scale (Kurbaş, Orhan and Topal, 2012) of a 5-point Likert rating type (agree, strongly agree, partially agree, neutral, disagree, strongly disagree) with 13 items. In this scale, the opinions of Social Studies teachers and Social Studies educators who participated in the research were taken into account, and the number of questions was increased to 18 items in the scale. A preliminary application was performed on 60 Social Studies teachers working in 25 secondary schools in Yakutiye and Palandöken districts of Erzurum province to ensure the content validity, intelligibility and reliability of the new scale developed, and the reliability coefficient Alpha of the scale was determined as 0.989 .

\subsection{Analysis of Data}

In analyzing the data as a result of the study, the data obtained were analyzed using SPSS 20.0 package program (percentage, frequency and chi-square test). Item-based frequency (n) and percentage (\%) were used in determining the teachers' opinions.

\section{Findings and Comments}

Table 1. Descriptive Statistics Related to Questions

\begin{tabular}{llllll}
\hline Questions & Number(n) & $\begin{array}{l}\text { Preferred } \\
\text { Score }\end{array}$ & Scale & $\begin{array}{l}\text { Arithmetic } \\
\text { Mean }(\mathrm{X})\end{array}$ & $\begin{array}{l}\text { Standard } \\
\text { Deviation }\end{array}$ \\
\hline Q-1 & 120 & 1,00 & 5,00 & 3,6667 & 1,064 \\
Q-2 & 120 & 1,00 & 5,00 & 3,8667 & 0,888 \\
Q-3 & 120 & 1,00 & 5,00 & 3,7250 & 0,987 \\
Q-4 & 120 & 1,00 & 5,00 & 3,9000 & 0,911 \\
Q-5 & 120 & 1,00 & 5,00 & 3,3500 & 0,904 \\
Q-6 & 120 & 1,00 & 5,00 & 3,7667 & 0,959 \\
Q-7 & 120 & 2,00 & 5,00 & 3,8750 & 0,836 \\
Q-8 & 120 & 1,00 & 5,00 & 3,4583 & 1,012 \\
Q-9 & 120 & 2,00 & 5,00 & 4,3167 & 0,673 \\
Q-10 & 120 & 2,00 & 5,00 & 2,8917 & 0,915 \\
Q-11 & 120 & 1,00 & 5,00 & 3,7083 & 1,024 \\
Q-12 & 120 & 1,00 & 5,00 & 2,6250 & 1,116 \\
Q-13 & 120 & 1,00 & 5,00 & 2,0833 & 1,042 \\
Q-14 & 120 & 1,00 & 5,00 & 2,4833 & 1,092 \\
Q-15 & 120 & 1,00 & 5,00 & 2,3333 & 0,947 \\
Q-16 & 120 & 2,00 & 5,00 & 2,8750 & 0,784 \\
Q-17 & 120 & 2,00 & 5,00 & 4,0000 & 0,82 \\
Q-18 & 120 & 1,00 & 5,00 & 4,2500 & 0,928 \\
\hline
\end{tabular}

When the teachers' opinions on the visual elements in Social Studies coursebooks were analyzed, the items of "Visuals that will misinform students and that will be a negative example for students are not included in the coursebook $(X=4,33167)$ ", "Visuals included in the coursebook are sufficient $(X=4,2500)$ " and "Visuals included in the texts are sufficient in reflecting the basic concepts $(\mathrm{X}=4,0000)$ " were the most positive responses with regard to the books and the arrangement of books. 
Table 2. Findings Concerning the Teachers' Opinions Related to the Visual Elements in Social Studies Coursebooks

\begin{tabular}{|c|c|c|c|c|c|c|c|c|c|c|}
\hline \multirow{2}{*}{$\begin{array}{l}\text { Questions Concerning the Teachers' Opinions } \\
\text { Related to the Visual Elements in Social Studies } \\
\text { Coursebooks }\end{array}$} & \multicolumn{2}{|c|}{$\begin{array}{l}\text { Strongly } \\
\text { Agree }\end{array}$} & \multicolumn{2}{|c|}{ Agree } & \multicolumn{2}{|c|}{ Neutral } & \multicolumn{2}{|c|}{ Disagree } & \multicolumn{2}{|c|}{$\begin{array}{l}\text { Strongly } \\
\text { Disagree }\end{array}$} \\
\hline & $\mathrm{n}$ & $\%$ & $\mathrm{n}$ & $\%$ & $\mathrm{n}$ & $\%$ & $\mathrm{n}$ & $\%$ & $\mathrm{n}$ & $\%$ \\
\hline $\begin{array}{l}\text { 1. Visuals included in the coursebook are appropriat } \\
\text { to the age level of students. }\end{array}$ & 23 & 19,17 & 58 & 48,33 & 22 & 18,33 & 10 & 8,33 & 7 & 5,83 \\
\hline $\begin{array}{l}\text { 2. Visuals are appropriate to the content of the text } \\
\text { in which they are included. }\end{array}$ & 26 & 21,67 & 64 & 53,33 & 20 & 16,67 & 8 & 6,67 & 2 & 1,67 \\
\hline $\begin{array}{l}\text { 3. Visuals have the quality to help a better } \\
\text { explanation/understanding of the subject. }\end{array}$ & 25 & 20,83 & 55 & 45,83 & 25 & 20,83 & 12 & 10,00 & 3 & 2,50 \\
\hline $\begin{array}{l}\text { 4. Visuals have the quality to attract students' } \\
\text { interest. }\end{array}$ & 30 & 25,00 & 60 & 50,00 & 20 & 16,67 & 8 & 6,67 & 2 & 1,67 \\
\hline $\begin{array}{l}\text { 5. Visuals have the quality to motivate students on } \\
\text { the subject. }\end{array}$ & 13 & 10,83 & 35 & 29,17 & 56 & 46,67 & 13 & 10,83 & 3 & 2,50 \\
\hline $\begin{array}{l}\text { 6. Visuals included in the texts summarize the } \\
\text { subject. }\end{array}$ & 24 & 20,00 & 60 & 50,00 & 24 & 20,00 & 8 & 6,67 & 4 & 3,33 \\
\hline $\begin{array}{l}\text { 7. Visuals have the quality to support the } \\
\text { information given in the text. }\end{array}$ & 25 & 20,83 & 65 & 54,17 & 20 & 16,67 & 10 & 8,33 & 0 & 0,00 \\
\hline $\begin{array}{l}\text { 8. Visuals have the quality to be understood by } \\
\text { students. }\end{array}$ & 13 & 10,83 & 57 & 47,50 & 27 & 22,50 & 18 & 15,00 & 5 & 4,17 \\
\hline $\begin{array}{l}\text { 9. Visuals that will misinform students and that will } \\
\text { be a negative example for students are not included } \\
\text { in the coursebook. }\end{array}$ & 50 & 41,67 & 60 & 50,00 & 8 & 6,67 & 2 & 1,67 & 0 & 0,00 \\
\hline $\begin{array}{l}\text { 10. Visuals have the quality to express similarities } \\
\text { and differences between past and present by } \\
\text { analyzing the representative pictures in the } \\
\text { coursebook. }\end{array}$ & 7 & 5,83 & 23 & 19,17 & 40 & 33,33 & 50 & 41,67 & 0 & 0,00 \\
\hline $\begin{array}{l}\text { 11. Visual materials and different figures help } \\
\text { students to get to know different cultures and to } \\
\text { become socialized. }\end{array}$ & 25 & 20,83 & 55 & 45,83 & 25 & 20,83 & 10 & 8,33 & 5 & 4,17 \\
\hline $\begin{array}{l}\text { 12. Tables and graphics are understandable in the } \\
\text { teaching of unit subjects in the coursebooks. }\end{array}$ & 10 & 8,33 & 20 & 16,67 & 15 & 12,50 & 65 & 54,17 & 10 & 8,33 \\
\hline 13. Maps are understandable by students. & 5 & 4,17 & 10 & 8,33 & 10 & 8,33 & 60 & 50,00 & 35 & 29,17 \\
\hline $\begin{array}{l}\text { 14. Sample visuals taken from the Internet help to } \\
\text { understand the subject. }\end{array}$ & 8 & 6,67 & 12 & 10,00 & 30 & 25,00 & 50 & 41,67 & 20 & 16,67 \\
\hline $\begin{array}{l}\text { 15. Caricatures included in the texts are appropriate } \\
\text { to student levels. }\end{array}$ & 5 & 4,17 & 10 & 8,33 & 20 & 16,67 & 70 & 58,33 & 15 & 12,50 \\
\hline $\begin{array}{l}\text { 16. Visuals given at the beginning of the unit are } \\
\text { sufficient to provide general information about the } \\
\text { unit. }\end{array}$ & 5 & 4,17 & 15 & 12,50 & 60 & 50,00 & 40 & 33,33 & 0 & 0,00 \\
\hline $\begin{array}{l}\text { 17. Visuals included in the texts are sufficient in } \\
\text { reflecting the basic concepts. }\end{array}$ & 30 & 25 & 70 & 58,33 & 10 & 8,33 & 10 & 8,33 & 0 & 0,00 \\
\hline 18.Visualsincluded in the coursebook are sufficient. & 60 & 50,00 & 40 & 33,33 & 10 & 8,33 & 10 & 8,33 & 0 & 0,00 \\
\hline
\end{tabular}

The items of "Visuals have the quality to attract students' interest. (X=3,9000)", "Visuals have the quality to support the information given in the text. $(\mathrm{X}=3,8750)$ ", "Visuals are appropriate to the content of the text in which they are included. $(3,8667)$ ", "Visuals included in the texts summarize the subject. $(X=3,7667)$ ", "Visuals have the quality to help a better explanation/understanding of the subject. $(\mathrm{X}=3,7250)$ ", "Visual materials and different figures help students to get to know different cultures and to become socialized. $(\mathrm{X}=3,7083)$ " and "Visuals included in the coursebook are appropriate to the age level of students. $(\mathrm{X}=3,6667)$ " can be considered as sufficient.

The items of "Visuals have the quality to be understood by students. (X=3,4583)", "Visuals have the quality to motivate students on the subject. ( $\mathrm{X}=3,3500)$ ", "Visuals have the quality to express similarities and differences between past and present by analyzing the representative pictures in the coursebook. (X=2,8917)", "Visuals given at the beginning of the unit are sufficient to provide general information about the unit. $(\mathrm{X}=2,8750)$ ") and "Tables and graphics are understandable in the teaching of unit subjects in the coursebooks. ( $\mathrm{X}=2,6250)$ " can be considered as neutral.

The items of "Sample visuals taken from the Internet help to understand the subject $(\mathrm{X}=2,4833)$ ", "Caricatures included in the texts are appropriate to student levels $(\mathrm{X}=2,3333)$ " and "Maps are understandable by students $(\mathrm{X}=2,0833)$." can be considered as insufficient. 
Table 3. Demographic Features of Social Studies Teachers by the Variable of Gender $(\mathrm{N}=70)$

\begin{tabular}{lll}
\hline Demographic Features & N & \% \\
\hline Female & 47 & 39.17 \\
Male & 73 & 60.83 \\
Total & 120 & 100 \\
\hline
\end{tabular}

As it can be understood from Table 3,60.83\% of teachers were male, and $39.17 \%$ of them were female, and the ratio of males appears to be higher in the general gender distribution.

Table 4. Demographic Features of Social Studies Teachers by the Variable of Seniority $(\mathrm{N}=70)$

\begin{tabular}{ccc}
\hline Demographic Features & $\mathbf{N}$ & $\%$ \\
\hline $1-15$ & 59 & 49.17 \\
$16+$ & 61 & 50.83 \\
Total & 120 & 100 \\
\hline
\end{tabular}

As it can be understood from Table 4 , it is seen that $49.17 \%$ of teachers have professional experience of between $1-15$ years and that $50.83 \%$ of them have professional experience of 16 years and above.

Table 5. Demographic Features of Social Studies Teachers by the Variable of the Faculty of Graduation $(\mathrm{N}=70)$

\begin{tabular}{lll}
\hline Demographic Features & $\mathbf{N}$ & \% \\
\hline Science-Literature & 61 & 50.83 \\
Education & 59 & 49.17 \\
Total & 120 & 100 \\
\hline
\end{tabular}

As it can be understood from Table 5, it is seen that $50.83 \%$ of teachers graduated from the Faculty of Science and Literature and that $49.17 \%$ of them graduated from the Faculty of Education.

Table 6. Social Studies Teachers' Opinions Related to Visual Materials by the Status of Gender

\begin{tabular}{|c|c|c|c|c|}
\hline Questions & Group & $\mathrm{N}$ & Chi-Square & $\mathrm{P}$ \\
\hline $\begin{array}{l}\text { 1. Visuals included in the coursebook are appropriate to the age level of } \\
\text { students. }\end{array}$ & $\begin{array}{l}\mathrm{M} \\
\mathrm{F}\end{array}$ & $\begin{array}{l}73 \\
47\end{array}$ & 29,741 & $0,000 * *$ \\
\hline 2. Visuals are appropriate to the content of the text in which they are included. & $\begin{array}{l}\mathrm{M} \\
\mathrm{F}\end{array}$ & $\begin{array}{l}73 \\
47\end{array}$ & 12,416 & $0,015^{*}$ \\
\hline $\begin{array}{l}\text { 3. Visuals have the quality to help a better explanation/understanding of the } \\
\text { subject. }\end{array}$ & $\begin{array}{l}\mathrm{M} \\
\mathrm{F}\end{array}$ & $\begin{array}{l}73 \\
47\end{array}$ & 6,477 & 0,166 \\
\hline 4. Visuals have the quality to attract students' interest. & $\begin{array}{l}\mathrm{M} \\
\mathrm{F}\end{array}$ & $\begin{array}{l}73 \\
47\end{array}$ & 15,241 & $0,004 * *$ \\
\hline 5. Visuals have the quality to motivate students on the subject. & $\begin{array}{l}\mathrm{M} \\
\mathrm{F}\end{array}$ & $\begin{array}{l}73 \\
47\end{array}$ & 10,504 & $0,033 *$ \\
\hline 6. Visuals included in the texts summarize the subject. & $\begin{array}{l}\mathrm{M} \\
\mathrm{F}\end{array}$ & $\begin{array}{l}73 \\
47\end{array}$ & 14,178 & $0,007 * *$ \\
\hline 7. Visuals have the quality to support the information given in the text. & $\begin{array}{l}\mathrm{M} \\
\mathrm{F}\end{array}$ & $\begin{array}{l}73 \\
47\end{array}$ & 10,362 & $0,016^{*}$ \\
\hline 8. Visuals have the quality to be understood by students. & $\begin{array}{l}\mathrm{M} \\
\mathrm{F}\end{array}$ & $\begin{array}{l}73 \\
47\end{array}$ & 7,308 & 0,120 \\
\hline $\begin{array}{l}\text { 9. Visuals that will misinform students and that will be a negative example for } \\
\text { students are not included in the coursebook. }\end{array}$ & $\begin{array}{l}\mathrm{M} \\
\mathrm{F}\end{array}$ & $\begin{array}{l}73 \\
47\end{array}$ & 6,331 & 0,97 \\
\hline $\begin{array}{l}\text { 10. Visuals have the quality to express similarities and differences between } \\
\text { past and present by analyzing the representative pictures in the coursebook. }\end{array}$ & $\begin{array}{l}\mathrm{M} \\
\mathrm{F}\end{array}$ & $\begin{array}{l}73 \\
47\end{array}$ & 10,547 & $0,014^{*}$ \\
\hline $\begin{array}{l}\text { 11. Visual materials and different figures help students to get to know } \\
\text { different cultures and to become socialized. }\end{array}$ & $\begin{array}{l}\mathrm{M} \\
\mathrm{F}\end{array}$ & $\begin{array}{l}73 \\
47\end{array}$ & 18,626 & $0,001 * *$ \\
\hline $\begin{array}{l}\text { 12. Tables and graphics are understandable in the teaching of unit subjects in } \\
\text { the coursebooks. }\end{array}$ & $\begin{array}{l}\mathrm{M} \\
\mathrm{F}\end{array}$ & $\begin{array}{l}73 \\
47\end{array}$ & 4,558 & 0,336 \\
\hline 13. Maps are understandable by students. & $\begin{array}{l}\mathrm{M} \\
\mathrm{F}\end{array}$ & $\begin{array}{l}73 \\
47\end{array}$ & 30,284 & $0,000 * *$ \\
\hline 14. Sample visuals taken from the Internet help to understand the subject. & $\begin{array}{l}\mathrm{M} \\
\mathrm{F}\end{array}$ & $\begin{array}{l}73 \\
47\end{array}$ & 7,465 & 0,113 \\
\hline 15. Caricatures included in the texts are appropriate to student levels. & $\begin{array}{l}\mathrm{M} \\
\mathrm{F}\end{array}$ & $\begin{array}{l}73 \\
47\end{array}$ & 15,028 & $0,005 * *$ \\
\hline $\begin{array}{l}\text { 16. Visuals given at the beginning of the unit are sufficient to provide general } \\
\text { information about the unit. }\end{array}$ & $\begin{array}{l}\mathrm{M} \\
\mathrm{F}\end{array}$ & $\begin{array}{l}73 \\
47\end{array}$ & 3,361 & 0,339 \\
\hline 17. Visuals included in the texts are sufficient in reflecting the basic concepts. & $\begin{array}{l}\mathrm{M} \\
\mathrm{F}\end{array}$ & $\begin{array}{l}73 \\
47\end{array}$ & 1,565 & 0,667 \\
\hline 18. Visuals included in the coursebook are sufficient. & $\begin{array}{l}\mathrm{M} \\
\mathrm{F}\end{array}$ & $\begin{array}{l}73 \\
47\end{array}$ & 0,853 & 0,837 \\
\hline
\end{tabular}

$*: \mathrm{p}<0.05$

$* *: \mathrm{p}<0.01$ 
According to the chi-square test results;

1. Among the answers given to the questions of "Visuals included in the coursebook are appropriate to the age level of students. (Q -1., $\mathrm{p}=0,000)$ ), "Visuals have the quality to attract students' interest. (Q-4., $\mathrm{p}=0,004)$ ), "Visuals included in the texts summarize the subject. (Q-6., $\mathrm{p}=0,007)$ ", "Visual materials and different figures help students to get to know different cultures and to become socialized. (Q-11., $\mathrm{p}=0,001)$ ", "Maps are understandable by students. (Q-13., $\mathrm{p}=0,000)$ " and "Caricatures included in the texts are appropriate to student levels. (Q-15., $\mathrm{p}=0,005)$ ", it was determined that female teachers had a more positive point of view in terms of gender compared to male teachers.

2. Among the answers given to the questions of "Visuals are appropriate to the content of the text in which they are included. (Q-2., $\mathrm{p}=0,015)$ ", "Visuals have the quality to motivate students on the subject. (Q-5., $\mathrm{p}=0,033)$ ", "Visuals have the quality to support the information given in the text. (Q-7., $\mathrm{p}=0,016)$,", Visuals have the quality to express similarities and differences between past and present by analyzing the representative pictures in the coursebook. (Q-10., $\mathrm{p}=0,014)$ ", a significant difference was found in terms of gender.

3. Among the answers given to the questions of "Visuals have the quality to help a better explanation/understanding of the subject. (Q-3., $\mathrm{p}=0,166)$ ", "Visuals have the quality to be understood by students. (Q-8., $\mathrm{p}=0,120)$ ), "Visuals that will misinform students and that will be a negative example for students are not included in the coursebook. (Q-9., $\mathrm{p}=0,97)$ ", "Tables and graphics are understandable in the teaching of unit subjects in the coursebooks. (Q-12., $\mathrm{p}=0,336)$ ", "Sample visuals taken from the Internet help to understand the subject. (Q-14., $\mathrm{p}=0,113)$ ), "Visuals given at the beginning of the unit are sufficient to provide general information about the unit (Q-16., $\mathrm{p}=0,339$ )", "Visuals included in the texts are sufficient in reflecting the basic concepts. (Q-17., $p=0,667$ )","Visuals included in the coursebook are sufficient. (Q-18., $\mathrm{p}=0,837$ )", no significant difference in terms of gender was found.

Table 7. Social Studies Teachers' Opinions Related to Visual Materials by the Variable of Seniority

\begin{tabular}{|c|c|c|c|c|}
\hline Questions & Group & $\mathrm{N}$ & Chi-Square & $\mathrm{P}$ \\
\hline $\begin{array}{l}\text { 1. Visuals included in the coursebook are appropriate to the age level of } \\
\text { students. }\end{array}$ & $\begin{array}{l}1-15 \\
16+\end{array}$ & $\begin{array}{l}59 \\
61\end{array}$ & 32,616 & $0,000 * *$ \\
\hline $\begin{array}{l}\text { 2. Visuals are appropriate to the content of the text in which they are } \\
\text { included. }\end{array}$ & $\begin{array}{l}1-15 \\
16+\end{array}$ & $\begin{array}{l}59 \\
61\end{array}$ & 12,354 & $0,015 *$ \\
\hline $\begin{array}{l}\text { 3. Visuals have the quality to help a better explanation/understanding of the } \\
\text { subject. }\end{array}$ & $\begin{array}{l}1-15 \\
16+\end{array}$ & $\begin{array}{l}59 \\
61\end{array}$ & 16,291 & $0,003 * *$ \\
\hline 4. Visuals have the quality to attract students' interest. & $\begin{array}{l}1-15 \\
16+\end{array}$ & $\begin{array}{l}59 \\
61\end{array}$ & 15,341 & $0,004 * *$ \\
\hline 5. Visuals have the quality to motivate students on the subject. & $\begin{array}{l}1-15 \\
16+\end{array}$ & $\begin{array}{l}59 \\
61\end{array}$ & 19,830 & $0,001 * *$ \\
\hline 6. Visuals included in the texts summarize the subject. & $\begin{array}{l}1-15 \\
16+\end{array}$ & $\begin{array}{l}59 \\
61\end{array}$ & 19,584 & $0,001 * *$ \\
\hline 7. Visuals have the quality to support the information given in the text. & $\begin{array}{l}1-15 \\
16+\end{array}$ & $\begin{array}{l}59 \\
61\end{array}$ & 17,055 & $0,001 * *$ \\
\hline 8. Visuals have the quality to be understood by students. & $\begin{array}{l}1-15 \\
16+\end{array}$ & $\begin{array}{l}59 \\
61\end{array}$ & 14,042 & $0,007 * *$ \\
\hline $\begin{array}{l}\text { 9. Visuals that will misinform students and that will be a negative example } \\
\text { for students are not included in the coursebook. }\end{array}$ & $\begin{array}{l}1-15 \\
16+\end{array}$ & $\begin{array}{l}59 \\
61\end{array}$ & 8,736 & $0,033 *$ \\
\hline $\begin{array}{l}\text { 10. Visuals have the quality to express similarities and differences between } \\
\text { past and present by analyzing the representative pictures in the coursebook. }\end{array}$ & $\begin{array}{l}1-15 \\
16+\end{array}$ & $\begin{array}{l}59 \\
61\end{array}$ & 11,252 & $0,01 * *$ \\
\hline $\begin{array}{l}\text { 11. Visual materials and different figures help students to get to know } \\
\text { different cultures and to become socialized. }\end{array}$ & $\begin{array}{l}1-15 \\
16+\end{array}$ & $\begin{array}{l}59 \\
61\end{array}$ & 12,549 & $0,014 *$ \\
\hline $\begin{array}{l}\text { 12. Tables and graphics are understandable in the teaching of unit subjects } \\
\text { in the coursebooks. }\end{array}$ & $\begin{array}{l}1-15 \\
16+\end{array}$ & $\begin{array}{l}59 \\
61\end{array}$ & 11,217 & $0,024 *$ \\
\hline 13. Maps are understandable by students. & $\begin{array}{l}1-15 \\
16+\end{array}$ & $\begin{array}{l}59 \\
61\end{array}$ & 15,666 & $0,004 * *$ \\
\hline 14. Sample visuals taken from the Internet help to understand the subject. & $\begin{array}{l}1-15 \\
16+\end{array}$ & $\begin{array}{l}59 \\
61\end{array}$ & 7,276 & 0,122 \\
\hline 15. Caricatures included in the texts are appropriate to student levels. & $\begin{array}{l}1-15 \\
16+\end{array}$ & $\begin{array}{l}59 \\
61\end{array}$ & 10,282 & $0,036^{*}$ \\
\hline $\begin{array}{l}\text { 16. Visuals given at the beginning of the unit are sufficient to provide } \\
\text { general information about the unit. }\end{array}$ & $\begin{array}{l}1-15 \\
16+\end{array}$ & $\begin{array}{l}59 \\
61\end{array}$ & 4,947 & 0,176 \\
\hline $\begin{array}{l}\text { 17. Visuals included in the texts are sufficient in reflecting the basic } \\
\text { concepts. }\end{array}$ & $\begin{array}{l}1-15 \\
16+\end{array}$ & $\begin{array}{l}59 \\
61\end{array}$ & 1,683 & 0,641 \\
\hline 18. Visuals included in the coursebook are sufficient. & $\begin{array}{l}1-15 \\
16+\end{array}$ & $\begin{array}{l}59 \\
61\end{array}$ & 10,509 & $0,015^{*}$ \\
\hline
\end{tabular}

$*: \mathrm{p}<0.05, * *: \mathrm{p}<0.01$ 
1. Among the answers given to the questions of "Visuals included in the coursebook are appropriate to the age level of students. (Q-1., $\mathrm{p}=0,000)$ ), "Visuals have the quality to help a better explanation/understanding of the subject. (Q-3., $\mathrm{p}=0,003$ )", "Visuals have the quality to attract students' interest. (Q-4., $\mathrm{p}=0,004)$ ), "Visuals have the quality to motivate students on the subject. (Q-5., $\mathrm{p}=0,001)$ ), "Visuals included in the texts summarize the subject. (Q-6., $\mathrm{p}=0,001)$ ", "Visuals have the quality to support the information given in the text. (Q-7., $\mathrm{p}=0,001$ )", "Visuals have the quality to be understood by students. (Q-8.,p=0,007)", "Visuals have the quality to express similarities and differences between past and present by analyzing the representative pictures in the coursebook. (Q-10., $\mathrm{p}=0,01$ )", "Maps are understandable by students. (Q-13., $\mathrm{p}=0,004)$ ", a very significant difference in terms of seniority did not appear.

2. Among the answers given to the questions of "Visuals are appropriate to the content of the text in which they are included. (Q-2., $\mathrm{p}=0,015)$ ", "Visuals that will misinform students and that will be a negative example for students are not included in the coursebook. (Q-9., $\mathrm{p}=0,033)$ ", "Visual materials and different figures help students to get to know different cultures and to become socialized. (Q-11., $\mathrm{p}=0,014)$ ", "Tables and graphics are understandable in the teaching of unit subjects in the coursebooks. ( $\mathrm{Q}-12$., $\mathrm{p}=0,024)$ ", "Caricatures included in the texts are appropriate to student levels. (Q-15., $\mathrm{p}=0,036)$ ", "Visuals included in the coursebook are sufficient. (Q-18., $\mathrm{p}=0,015)$ ", a significant difference was found in favor of teachers with 1-15 years of service in terms of seniority.

3. Among the answers given to the questions of "Sample visuals taken from the Internet help to understand the subject. (Q-14., $\mathrm{p}=0,122)$ ", "Visuals given at the beginning of the unit are sufficient to provide general information about the unit. (Q-16., $\mathrm{p}=0,176)$ ", "Visuals included in the texts are sufficient in reflecting the basic concepts. (Q-17., $p=0,641)$ ", no significant difference was found in terms of seniority.

Table 8. Social Studies Teachers' Opinions Related to Visual Materials by the Variable of the Faculty of Graduation

\begin{tabular}{|c|c|c|c|c|}
\hline Questions & Group & $\mathrm{N}$ & Chi-Square & $\mathrm{P}$ \\
\hline $\begin{array}{l}\text { 1. Visuals included in the coursebook are appropriate to the } \\
\text { age level of students. }\end{array}$ & $\begin{array}{l}\text { Science-Literature } \\
\text { Education }\end{array}$ & $\begin{array}{l}61 \\
59\end{array}$ & 32,616 & $0,000 * *$ \\
\hline $\begin{array}{l}\text { 2. Visuals are appropriate to the content of the text in which } \\
\text { they are included. }\end{array}$ & $\begin{array}{l}\text { Science-Literature } \\
\text { Education }\end{array}$ & $\begin{array}{l}61 \\
59\end{array}$ & 12,354 & $0,015^{*}$ \\
\hline $\begin{array}{l}\text { 3.Visuals have the quality to help a better } \\
\text { explanation/understanding of the subject. }\end{array}$ & $\begin{array}{l}\text { Science-Literature } \\
\text { Education }\end{array}$ & $\begin{array}{l}61 \\
59\end{array}$ & 16,291 & $0,003 * *$ \\
\hline 4. Visuals have the quality to attract students' interest. & $\begin{array}{l}\text { Science-Literature } \\
\text { Education }\end{array}$ & $\begin{array}{l}61 \\
59\end{array}$ & 15,341 & $0,004 * *$ \\
\hline 5. Visuals have the quality to motivate students on the subject. & $\begin{array}{l}\text { Science-Literature } \\
\text { Education }\end{array}$ & $\begin{array}{l}61 \\
59\end{array}$ & 19,830 & $0,001 * *$ \\
\hline 6. Visuals included in the texts summarize the subject. & $\begin{array}{l}\text { Science-Literature } \\
\text { Education }\end{array}$ & $\begin{array}{l}61 \\
59\end{array}$ & 19,584 & $0,001 * *$ \\
\hline $\begin{array}{l}\text { 7. Visuals have the quality to support the information given in } \\
\text { the text. }\end{array}$ & $\begin{array}{l}\text { Science-Literature } \\
\text { Education }\end{array}$ & $\begin{array}{l}61 \\
59\end{array}$ & 17,055 & $0,001 * *$ \\
\hline 8. Visuals have the quality to be understood by students. & $\begin{array}{l}\text { Science-Literature } \\
\text { Education }\end{array}$ & $\begin{array}{l}61 \\
59\end{array}$ & 14,042 & $0,007 * *$ \\
\hline $\begin{array}{l}\text { 9. Visuals that will misinform students and that will be a } \\
\text { negative example for students are not included in the } \\
\text { coursebook. }\end{array}$ & $\begin{array}{l}\text { Science-Literature } \\
\text { Education }\end{array}$ & $\begin{array}{l}61 \\
59\end{array}$ & 8,736 & $0,033 *$ \\
\hline $\begin{array}{l}\text { 10. Visuals have the quality to express similarities and } \\
\text { differences between past and present by analyzing the } \\
\text { representative pictures in the coursebook. }\end{array}$ & $\begin{array}{l}\text { Science-Literature } \\
\text { Education }\end{array}$ & $\begin{array}{l}61 \\
59\end{array}$ & 11,252 & $0,010 * *$ \\
\hline $\begin{array}{l}\text { 11. Visual materials and different figures help students to get } \\
\text { to know different cultures and to become socialized. }\end{array}$ & $\begin{array}{l}\text { Science-Literature } \\
\text { Education }\end{array}$ & $\begin{array}{l}61 \\
59\end{array}$ & 12,549 & $0,014 *$ \\
\hline $\begin{array}{l}\text { 12. Tables and graphics are understandable in the teaching of } \\
\text { unit subjects in the coursebooks. }\end{array}$ & $\begin{array}{l}\text { Science-Literature } \\
\text { Education }\end{array}$ & $\begin{array}{l}61 \\
59\end{array}$ & 11,217 & $0,024 *$ \\
\hline 13. Maps are understandable by students. & $\begin{array}{l}\text { Science-Literature } \\
\text { Education }\end{array}$ & $\begin{array}{l}61 \\
59\end{array}$ & 15,666 & $0,004 * *$ \\
\hline $\begin{array}{l}\text { 14. Sample visuals taken from the Internet help to understand } \\
\text { the subject. }\end{array}$ & $\begin{array}{l}\text { Science-Literature } \\
\text { Education }\end{array}$ & $\begin{array}{l}61 \\
59\end{array}$ & 7,276 & 0,122 \\
\hline $\begin{array}{l}\text { 15. Caricatures included in the texts are appropriate to student } \\
\text { levels. }\end{array}$ & $\begin{array}{l}\text { Science-Literature } \\
\text { Education }\end{array}$ & $\begin{array}{l}61 \\
59\end{array}$ & 10,282 & $0,036^{*}$ \\
\hline $\begin{array}{l}\text { 16. Visuals given at the beginning of the unit are sufficient to } \\
\text { provide general information about the unit. }\end{array}$ & $\begin{array}{l}\text { Science-Literature } \\
\text { Education }\end{array}$ & $\begin{array}{l}61 \\
59\end{array}$ & 4,947 & 0,176 \\
\hline $\begin{array}{l}17 \text {. Visuals included in the texts are sufficient in reflecting the } \\
\text { basic concepts. }\end{array}$ & $\begin{array}{l}\text { Science-Literature } \\
\text { Education }\end{array}$ & $\begin{array}{l}61 \\
59\end{array}$ & 1,683 & 0,641 \\
\hline 18. Visuals included in the coursebook are sufficient. & $\begin{array}{l}\text { Science-Literature } \\
\text { Education }\end{array}$ & $\begin{array}{l}61 \\
59 \\
\end{array}$ & 10,509 & $0,015^{*}$ \\
\hline
\end{tabular}

$*: \mathrm{p}<0.05$

$* *: \mathrm{p}<0.01$ 
1. Among the answers given to the questions of "Visuals included in the coursebook are appropriate to the age level of students. (Q-1., $\mathrm{p}=0,000)$ ), "Visuals have the quality to help a better explanation/understanding of the subject. (Q-3., $\mathrm{p}=0,003)$ ", "Visuals have the quality to attract students' interest. (Q-4., $\mathrm{p}=0,004)$ ", "Visuals have the quality to motivate students on the subject. (Q-5., $\mathrm{p}=0,001)$ ", "Visuals included in the texts summarize the subject. (Q-6., $\mathrm{p}=0,001)$ ", "Visuals have the quality to support the information given in the text. (Q-7., $\mathrm{p}=0,001)$ ", "Visuals have the quality to be understood by students. (Q-8., $\mathrm{p}=0,007)$ ", "Visuals have the quality to express similarities and differences between past and present by analyzing the representative pictures in the coursebook. (Q-10., $\mathrm{p}=0,010)$ ", "Maps are understandable by students. (Q-13., $\mathrm{p}=0,004)$ ", a very significant difference was found in favor of teachers graduated from the Faculty of Education in terms of the faculty of graduation.

2. Among the answers given to the questions of "Visuals are appropriate to the content of the text in which they are included. (Q-2., $\mathrm{p}=0,015)$ ), "Visuals that will misinform students and that will be a negative example for students are not included in the coursebook. (Q-9., $\mathrm{p}=0,033)$ ", "Visual materials and different figures help students to get to know different cultures and to become socialized. (Q-11., $\mathrm{p}=0,014)$ ", "Tables and graphics are understandable in the teaching of unit subjects in the coursebooks. (Q-12., $\mathrm{p}=0,024)$ ", "Caricatures included in the texts are appropriate to student levels. (Q-15., $\mathrm{p}=0,036)$ ", "Visuals included in the coursebook are sufficient. (Q-18., $\mathrm{p}=0,015)$ ", a significant difference was found in favor of teachers graduated from the Faculty of Education in terms of the faculty of graduation.

3. Among the answers given to the questions of "Sample visuals taken from the Internet help to understand the subject. (Q-14., $\mathrm{p}=0,122)$ ", "Visuals given at the beginning of the unit are sufficient to provide general information about the unit. (Q-16., $\mathrm{p}=0,176)$ ", "Visuals included in the texts are sufficient in reflecting the basic concepts. (Q-17., $p=0,641)$ ", no significant difference was found in terms of the faculty of graduation.

\section{Conclusion and Discussion}

One of the factors that determine the effectiveness of visual materials included in coursebooks is the sense organ to which they appeal since the more a material appeals to sense organs, the more quickly and efficiently it achieves its goal, regardless of the stage of education. It is known that visual elements have an aspect of improving students' thinking, interpretation, understanding and explaining skills at the abstract and concrete thinking stages, especially at the concrete thinking stage. According to the statements of the teachers in our study group as a result of the study conducted in line with this purpose, visuals that will misinform students and that will be a negative example for students are not included in the Social Studies $7^{\text {th }}$-grade coursebook.

As a result of this study, according to the opinions of the teachers participating in the research, it was determined that female teachers had a more positive point of view compared to male teachers in the topics which are related to the facts that visuals included in the coursebook are appropriate to the age level of students, visuals have the quality to attract students' interest, visuals included in the texts summarize the subject, visual materials and different figures help students to get to know different cultures and to become socialized, maps are understandable by students and that caricatures included in the texts are appropriate to student levels.

Besides, it was revealed that the topics related to facts that visuals help a better explanation of the subject, they are understood by students, visuals included in the coursebooks are not at the level to misinform students and to be a negative example for students, tables and graphics in the coursebooks are understandable in the teaching of unit subjects, sample visuals taken from the Internet help to understand the subject, visuals given at the beginning of the unit are sufficient to provide general information about the unit, visuals included in the texts are sufficient in reflecting the basic concepts and that visuals included in the coursebook are sufficient were evaluated in the same characteristics in terms of both teacher groups.

When periods of service were taken into account, it was determined that teachers who worked between 1 and 15 years, compared to teachers who worked more than 15 years, argued that visuals included in the coursebook are appropriate to the age level of students, visuals help a better explanation of the subject, visuals have the quality to motivate students on the subject and to attract students' interest, visuals included in the texts can summarize the subject, visuals support the information given in the text and are understood by students, visuals reveal the similarities and differences between past and present by analyzing the representative pictures in the coursebook and that maps are understandable by students.

When the faculty of graduation was taken into account, teachers graduated from the Faculty of Education found the facts that visuals included in the coursebook are appropriate to the age level of students, visuals have the quality to help a better explanation of the subject, visuals have the quality to motivate students on the subject and to attract students' interest, visuals included in the texts summarize the subject, visuals have the quality to support the information given in the text, visuals have the quality to be understood by students, visuals have the quality to express similarities and differences between past and present by analyzing the representative pictures in the coursebook and that maps are understandable by students more sufficient. 


\section{Suggestions}

Based on the results of this research, the following suggestions can be offered:

1. Tables, graphics, and maps given for the teaching of unit subjects in coursebooks should have the quality to be more understandable by students.

2. Caricatures included in the texts should be appropriate to student levels, and sample visuals taken from the Internet should support the understanding of the subject.

3. Visual elements in the Social Studies coursebooks were determined to be insufficient in developing students' creative thinking skills. Accordingly, visual elements in the Social Studies coursebooks should be redesigned to develop creative thinking/thinking skills which are the basic skills included in the new Social Studies Curriculum.

4. This study performed is limited only to the $7^{\text {th }}$-grade coursebook. Researchers can perform the same study for other classes in secondary school.

5. Social Studies teachers' opinions should be taken for the use of visual elements while preparing the Social Studies coursebook.

6. In this study, visuals in the Social Studies coursebook were analyzed by taking into account the teachers' opinions; students' opinions about the related topic can also be taken by another study to be performed.

\section{References}

Aslan, Z., \& Doğdu, S. (1993). Eğitim Teknolojisi Uygulamaları ve Eğitim Araç-gereçleri. [Education Technology Applications and Educational Tools and Materials] Ankara: Tekışık Ofset.

Bleed, R. (2005). Visual Literacy in Higher Education. [Online]: Retrieved on 17 October, 2007.

Demiralp, N. (2007). Coğrafya Eğitiminde Materyaller ve 2005 Coğrafya Dersi Öğretim Programı, [Materials in Geography Education and 2005 Geography Course Curriculum] Kastamonu Education Journal, 15(1), 373-384.

Demirel, Ö., \& Kıroğlu, K. (2005). Konu Alanı Ders Kitabı İncelemesi. [Subject Area Coursebook Analysis] Ankara: Pegem A Yayıncilik.

Duru, K., \& Gürdal, A. (2002). İlköğretim Fen ve Teknoloji Dersinde Kavram Haritasılya ve Gruplara Kavram Haritası Çizdirilerek Öğretimin Öğrenci Başarısına Etkisi. [Effect of Training on Student Achievement in Elementary Science and Technology Course by the Concept Map and Having Groups Drawn Concept Maps] V. Ulusal Fen Bilimleri ve Matematik Eğitimi Kongresi, Bildiriler Kitabı, 1, 310-316, Ankara.

Güneş, F. (2002). Ders Kitaplarının İncelenmesi. [Examination of Coursebooks] Ankara: Ocak Yayınları.

İpek, İ. (2003). Bilgisayarlar, görsel tasarım ve görsel öğrenme stratejileri. [Computers, visual design and visual learning strategies] The Turkish Online Journal of Educational Technology 2(3), 68-76.

Kaptan, S. (1998). Bilimsel Araştırma ve İstatistik Teknikleri. [Scientific Research and Statistical Techniques] Ankara: Tekışık Web Ofset Tesisleri.

Karamustafaoğlu, O. (2006). Fen ve teknoloji öğretmenlerinin öğretim materyallerini kullanma düzeyleri: [Science and technology teachers' using levels of teaching materials] Amasya ili örneği. Atatürk Üniversitesi Bayburt Eğitim Fakültesi Dergisi, 1(1), 90-101.

Kılıç, A., \& Seven, S. (2003). Konu Alanı Ders Kitabı İncelemesi. [Subject Area Coursebook Analysis] Ankara: Pegem A Yayincilik.

Kırbaş, A., Topal, Y., \& Orhan, S. (2012). İlköğretim Türkçe Ders Kitaplarındaki Görsel Ögelere Öğretmen Görüşlerinden Hareketle Eleştirel Bir Bakış, [A Critical Review of Visual Elements in Primary Education Turkish Coursebooks Based on Teachers' Opinions] Turkish Studies-International Periodical For The Languages, Literature and History of Turkish or Turkic, 7(4), 2225-2235.

Küçükahmet, L. (2001). Konu Alanı Ders Kitabı İnceleme. [Subject Area Coursebook Analysis] Ankara: Nobel Yayınları.

Nelson, M. R. (1992). Children and Social Studies. Harcount Brace Jovanovich Collage Publishers.

Yalçın, P. (2003). Maddeyi Tanıma Ünitesinin Kavratılmasında Görsel Öğretim Materyallerinin Etkisi Üzerine Bir Araştırma. [A Research on the Effects of Visual Teaching Materials in Comprehending the Substance Identification Unit] Kastamonu Eğitim Dergisi, 115.

Prensky, M. (2001). Digital Natives, Digital Immigrants, MCB University Press, 9(5). 
Şahin, Y. T., \& Yıldırım, S. (1999). Öğretim Teknolojileri ve Materyal Geliştirme. [Instructional Technologies and Material Development] Ankara: Anı Yayıncılık.

Taş, A. M. (2007).Yeni Sosyal Bilgiler Ders Kitaplarına İlişkin Öğretmen Görüşlerinin Belirlenmesi.[Determination of Teachers' Opinions Related to New Social Studies Coursebooks] Selçuk Üniversitesi Sosyal Bilimler Enstitüsü Dergisi, 17, 519-532.

Yanpar, T. (2005). Öğretim Teknolojileri ve Materyal Geliştirme. [Instructional Technologies and Material Development] Ankara: Anı Yayıncılık.

This work is licensed under a Creative Commons Attribution 3.0 License. 